\title{
Modeling Dynamics of Metal Price Series via State Space Approach with Two Common Factors
}

Vasyl Golosnoy, Anja Rossen

\section{HWWI Research}

Paper 156 


\author{
Vasyl Golosnoy \\ Department of Statistics and Econometrics \\ Ruhr University Bochum \\ vasyl.golosnoy@rub.de \\ Anja Rossen \\ Hamburg Institute of International Economics (HWWI) \\ Heimhuder Str. 71 | 20148 Hamburg | Germany \\ Phone: +49 (0)40 340576 - 347 | Fax: +49 (0)40 340576 - 776 \\ rossen@hwwi.org \\ HWWI Research Paper \\ Hamburg Institute of International Economics (HWWI) \\ Heimhuder Str. 71 | 20148 Hamburg | Germany \\ Phone: +49 (0)40 340576 - 0 | Fax: +49 (0)40 340576 - 776 \\ info@hwwi.org |www.hwwi.org \\ ISSN 1861-504X
}

Editorial Board:

PD Dr. Christian Growitsch (Chair)

Prof. Dr. Henning Vöpel

Dr. Christina Boll

(c) Hamburg Institute of International Economics (HWWI)

November 2014

All rights reserved. No part of this publication may be reproduced, stored in a retrieval system, or transmitted in any form or by any means (electronic, mechanical, photocopying, recording or otherwise) without the prior written permission of the publisher. 


\title{
Modeling Dynamics of Metal Price Series
}

\section{via State Space Approach with Two Common Factors}

\author{
Vasyl Golosnoy* and Anja Rossen ${ }^{\dagger}$
}

November 13, 2014

\begin{abstract}
In this paper we model the dynamics of 100 years long monthly price series of eight non-ferrous and precious metals. Applying the state space framework we impose and identify two common factors related to non-ferrous and precious metals, respectively, which exhibit quite distinct autoregressive dynamics. The preferred two common factor specifications outperform single common factor approaches which are usually used in the current literature. Furthermore, we provide interpretation for the extracted common factors by investigating their exposure to the major macroeconomic fundamentals.
\end{abstract}

Keywords: state space models; Kalman filter; non-ferrous metals; precious metals.

JEL: C32, C52, E30, F00

${ }^{*}$ Department of Statistics and Econometrics, Ruhr-Universität Bochum, E-mail address: vasyl.golosnoy@rub.de

${ }^{\dagger}$ Hamburg Institute of International Economics (HWWI), E-mail address: rossen@hwwi.org 


\section{Introduction}

The assessment of commodity price dynamics is of much importance for understanding global economic activity. The dramatic increase in commodity prices during the last decade renewed interest in modeling their behavior (cf. Humphreys 2010, Arezki et al., 2014). Metals constitute an important subset of nonagricultural and non-fuel commodities, which are related to both real economy due to business cycles (cf. Cashin et al. 2002, Akram 2009, Erten and Ocampa 2013) and monetary issues (cf. Frankel 2008, Hammoudeh and Yuan 2008, Arango et al. 2012). This study elaborates a state space specification for the 100 years long monthly time series of non-ferrous and precious metals, with the major aim to find an appropriate dynamic representation. In particular, we investigate whether a model with two common factors is more suitable for an adequate assessment of metal dynamics than the commonly used single common factor specification.

Metal price series are typically characterized by the following stylized features: they share common trends (cf. Jerrett and Cuddington 2008, Roberts 2009, Byrne et al. 2013); exhibit outliers as sharp price peaks (Deaton and Laroque 1992, Cashin and McDermott 2002) and are strongly cross- and autocorrelated. These empirical properties of metal series should be incorporated into a formal model framework. In the current literature (Labys et al. 1999, Lombardi et al. 2012, Byrne et al. 2013) a class of linear factor models with a single common and several idiosyncratic (individual) factors is mainly exploited in order to reflect all these characteristics with the exception of individual peaks. The common factor is responsible for the joint dynamics of the series whereas individual factors are introduced in order to cope with residual autocorrelation (Labys et al. 1999). The obtained empirical results indicate that the extracted common factor is positively correlated to the major macroeconomic fundamentals such as industrial production, consumer or stock prices, and negatively correlated with real interest rates.

Despite the popularity of the single common factor models, there are both theoretical (cf. Kose et al. 2004, Bernanke et al. 2005) and empirical (cf. Lombardi et al. 2012) arguments which indicate that a single common factor may not always be sufficient for a full description of the economic system. For example, 
a separation between real (e.g., industrial production) and nominal (inflation-related) economic indicators suggests that there should be at least two factors in order to describe the dynamics of metal price series. Another motivation for introducing the second common factor is the evidence that production and monetary shocks in the global economy have quite different impact on metal prices (cf. Belke et al. 2010, 2013).

For these reasons we consider a set of linear state space models with two common factors. The benchmark model as in Labys et al. (1999) and Vansteenkiste (2009) with a single common and several individual factors (states) is contrasted to more general approaches presuming two common factors with a number of individual factors. Since some parameters of these general models appear to be insignificant, we introduce zero restriction on factors loadings in order to find a suitable but parsimonious specification. A natural way to impose such zero restrictions on common factor loadings is to group non-ferrous (colored) and precious metals, which is motivated by the structure of their correlation matrix. We estimate all models by means of the Kalman filter approach both for the full sample (100 years) and for two subsamples (50 years each) in order to check the robustness of the obtained results.

Our findings support the necessity to introduce the second common factor for a better assessment of metal price development according to both log-likelihood and AIC/BIC. The second common factor, which is related to precious metals, exhibits quite distinct autoregressive dynamics compared to the first common factor. Both factors are positively correlated, moreover, some idiosyncratic factors are still necessary in order to remove remaining residual autocorrelation. The subsample analysis shows that the single common factor appears to be sufficient for the turbulent first half of the 20th century, whereas two common factors are necessary in the much more calm and peaceful second half of the sample characterized by a substantial increase in international trade.

Furthermore, we investigate empirically the relation of the extracted (filtered) common factors to macroeconomic fundamentals. We discover that the first common factor is more related to the industrial production and Standard \& Poor's 500 index, whereas the second common factor is positively correlated to oil prices and consumer price index. This finding implies that macroeconomic fundamentals representing real economy are 
more related to the first (non-ferrous metals) factor, whereas the second (precious metals) factor is mostly correlated with monetary variables. Thus, our results underscore the necessity of two common factors for modeling dynamics of metal prices.

The rest of the paper is organized as follows. In Section 2 we present the dataset and provide the descriptive analysis. In Section 3 we introduce linear state space models with common and idiosyncratic factors. The estimation results are provided in Section 4 where we also investigate the relationship between the extracted common factors and the major macroeconomic variables. Section 5 concludes the paper.

\section{Data Description}

We consider a unique dataset of eight non-ferrous and precious metal price series, which can be naturally divided in two groups of five non-ferrous (tin, zinc, lead, copper and aluminum) and three precious (gold, silver, platinum) metals. Our study is focused on modeling metal price dynamics over a long period of time which starts in 1910 and ends in 2011 with 1224 monthly observations in total. This data length is an advantage compared to the earlier studies which are mostly restricted to the history of the recent 50-60 years (as Labys et al. 1999 and Vansteenkiste 2009) or are based on yearly data frequency (as Byrne et al. 2013 and Lombardi et al. 2012). The detailed information about the data sources is provided in the Appendix.

Since the price series of interest seem to be integrated of order one, we calculate monthly returns by building the first log differences as in Lombardi et al. (2012). This transformation removes possible longrun cointegration relations from the data which are studied by Issler et al. (2014). Hence, we concentrate on modeling of the joint short- and medium-run dynamics of metal prices. Additionally, we standardize return series by subtracting the full sample means and dividing by the full sample standard deviations as it is commonly done in factor analysis. The same transformation is conducted for the considered macroeconomic series, namely the U.S. industrial production (ip), Standard \& Poor's 500 index (sp500), oil price (oil), consumer price index (cpi) and the real interest rate (int). The important full sample descriptive statistics 
for all metal and macroeconomic series are provided in Table 1, whereas the autocorrelation plots of the (standardized) first log differences of metal prices are shown in Figure 1. The pairwise full sample correlations between all time series are reported in Table 2 .

[Table 1 (descriptive stats), Table 2 (correlations), Figure 1 about here.]

The metal series exhibit pronounced autocorrelation, which appears to be of AR(1)-order according to the Bayes information criterion in the majority of cases. The normality assumption is strongly rejected for all series due outliers which produce heavy tails. The found ARCH effects point on heteroscedasticity in metal series as also reported by Hammoudeh et al. (2011). In particular, it is to differentiate between low volatility in the first half of the sample (especially during the World War II) and high volatility in the second half which is attributed (among other reasons) to the increasing volume of international trade in the globalization era. However, as the overall level of variability remains almost constant over time, we conduct our analysis without specifying an explicit model for conditional heteroscedasticity.

The cross-correlation analysis in Table 2 illustrates that metal series are significantly positively correlated to each other. This evidence suggests the existence of common dynamics which is well-documented in numerous studies starting from Pindyck and Rotemberg (1990). There are two distinct groups which unite the colored and precious metals, respectively, so that correlations are stronger within groups than between them. We exploit this evidence for imposing zero restrictions on factor loadings by estimating models with two common factors. Concerning the selected metal pairs, we report that gold and silver prices exhibit the highest correlation among all precious metals series which confirms findings of Soytas et al. (2009) and Sari et al. (2010). These precious metals (differently to platinum) are often considered as an investment opportunity and exhibits a "safe haven" function, i.e. demand on them increases dramatically in crisis times (cf. Baur and McDermott 2010). As in Agbeyegbe (1992), copper and lead prices exhibit the highest correlation among the colored metals.

Analyzing correlations between macro variables, note that we observe significantly positive correlation only between oil and cpi, and significantly negative correlations only for the interest rate with industrial 
production and cpi. The evidence about correlations between macro variables and metals is rather mixed. Industrial production and sp500 are mostly significantly positively correlated only to the colored metals, whereas oil and cpi are significantly positively correlated to almost all colored and precious metals. Finally, all metals (with the exception of gold) are significantly negatively correlated with the real interest rate as it is well documented in the literature (cf. Frankel 1986, Akram 2009, Batten et al. 2010).

\section{State Space Model Specifications}

The empirical literature dealing with commodity price series primarily aims to reveal their common autoregressive dynamics, which can be exploited for the forecasting purposes (cf. Issler et al. 2014). A family of linear factor models with both common and individual factors provides an appropriate econometric framework for this purpose. In this section we introduce the econometric specifications by starting with a basic model characterized by a single common and several individual factors (cf. Labys et al. 1999 and Vansteenkiste 2009). Next, we consider a set of more general state space models where the dynamics driven by two common factors and a number of individual factors.

\subsection{A single common factor: the benchmark}

Denote by $\mathbf{y}_{t}$ the $k$-dimensional series of the standardized first log differences of monthly metal prices. The model of Labys et al. (1999) with a single common factor and $k$ individual factors with AR(1) dynamics is chosen as a benchmark in our study. Whereas the common factor is responsible for the assessment of joint comovements, idiosyncratic (metal-specific) factors are necessary for modeling residual autocorrelations. The corresponding state space model with a single common factor $\xi_{t}$ and the $k$-dimensional vector of idiosyncratic 
factors $\zeta_{t}$ is specified as

$$
\begin{aligned}
\mathbf{y}_{t} & =\mathbf{h} \xi_{t}+\mathbf{h}_{i} \odot \boldsymbol{\zeta}_{t}+\mathbf{u}_{t}, \quad \mathbf{u}_{t} \sim(\mathbf{0}, \mathbf{R}), \\
\xi_{t} & =\phi \xi_{t-1}+e_{t}, \quad e_{t} \sim(0,1), \\
\boldsymbol{\zeta}_{t} & =\mathbf{f} \odot \boldsymbol{\zeta}_{t-1}+\varepsilon_{t}, \quad \varepsilon_{t} \sim \mathcal{N}(\mathbf{0}, \mathbf{I}),
\end{aligned}
$$

where $\odot$ denotes element-by-element vector multiplication. The iid innovations $\mathbf{u}_{t}, e_{s}, \boldsymbol{\varepsilon}_{v}$, are assumed to be mutually independent for all $t, s, v$; the covariance matrix $\mathbf{R}$ is presumed to be diagonal. The variances of factor innovations $e_{t}$ and $\varepsilon_{s}$ are set to be unity, which is the identification assumption. The vectors $\mathbf{h}$, $\mathbf{h}_{i}$ represent common and individual factor loadings, respectively. The individual factors are assumed to be independent on the common factor with all factors assumed to follow AR(1) dynamics. Recall that an additive representation of two lower order AR processes can be equivalent to presuming much more complex autoregressive specifications in the original series. Note also that the introduced state state specification allows for heteroscedasticity in the process $\mathbf{y}_{t}$ because of the time varying Kalman filter update of the mean squared error (cf. Hamilton 1994, p. 381).

\subsection{Models with two common factors}

Although the benchmark model with a single common and $k$ individual factors describes much of the metal price co-movements, there are both economic and statistical arguments for the introduction of an additional common factor into the system (cf. Kose et al. 2004, Bernanke et al. 2005). The economic motivation of the second common factor is a necessity to differentiate between the real (production) economy and monetary issues (cf. Pindyck and Rotemberg 1990). In particular, it is well-documented that commodity (metal) prices are related to industrial production (cf. Byrne et al. 2013, Akram 2009, Arango et al. 2012), which is one of the leading indicators for the business cycle. Moreover, metal prices are usually correlated with monetary (inflation-based) indicators, such as consumer price index or interest rates (cf. Frankel 2008).

Now we introduce a class of models with two common and several individual factors. As earlier, we assume that all factors follow AR(1) dynamics. The general representation with two common $\xi_{1, t}, \xi_{2, t}$ and 
the vector of $k$ individual factors $\boldsymbol{\zeta}_{t}$ is given in the following system of equations:

$$
\begin{array}{rlrl}
\mathbf{y}_{t} & =\mathbf{h}_{1} \xi_{1, t}+\mathbf{h}_{2} \xi_{2, t}+\mathbf{h}_{i} \odot \boldsymbol{\zeta}_{t}+\mathbf{u}_{t}, & & \mathbf{u}_{t} \sim(\mathbf{0}, \mathbf{R}), \\
\xi_{1, t} & =\phi_{1} \xi_{1, t-1}+e_{1, t}, & e_{1, t} \sim(0,1), & \\
\xi_{2, t}=\phi_{2} \xi_{2, t-1}+e_{2, t}, & e_{2, t} \sim(0,1), & \operatorname{Corr}\left(e_{1, t}, e_{2, t}\right)=\rho, \\
\boldsymbol{\zeta}_{t} & =\mathbf{f} \odot \boldsymbol{\zeta}_{t-1}+\varepsilon_{t}, & \varepsilon_{t} \sim \mathcal{N}(\mathbf{0}, \mathbf{I}), &
\end{array}
$$

with the assumption that the innovations $e_{1, t}, e_{2, t}$ and $\varepsilon_{t}$ are iid. The idiosyncratic factors are assumed to be uncorrelated to the common factors. However, we allow for correlation between the common factors (states), which is justified in the economic theory where aggregate output revisions are correlated to the unexpected changes in the money supply (Lucas and Sargent 1979). The vectors $\mathbf{h}_{1}, \mathbf{h}_{2}$ and $\mathbf{h}_{i}$ denote factor loadings for a pair of common and the vector of idiosyncratic factors, respectively. Again, we assume that $\mathbf{R}$ is a diagonal matrix. Similarly to the single common factor approach, this model can be estimated via Kalman filter approach (cf. Hamilton 1994).

The state space model with two common factors introduced in Equations (4)-(7) is quite general and could be overparameterized. Thus, our aim is to specify a parsimonious model with significant AR(1) factor coefficients as well as significant factor loadings such that it is able to remove residual autocorrelation. A fully unrestricted model (the estimates for this model are not reported here) provides many insignificant factor loadings as well as insignificant AR coefficients for individual factors. For this reason we investigate which zero restrictions on parameters could be imposed without losing model adequacy.

In order to address these empirical issues we investigate whether two common factors exhibit distinct autoregressive dynamics and provide significant factor loadings for all metals. Then we check whether it is necessary to introduce all $k=8$ individual factors in order to purge residual autocorrelation or a smaller number of individual factors is sufficient for this purpose. Moreover, we analyze whether zero restrictions on common factor loadings $\mathbf{h}_{1}, \mathbf{h}_{2}$ could be imposed without worsening of the model fit. Finally, we have to check whether the preferred full sample specification remains robust by considering subsamples. 


\section{Empirical Evidence}

All introduced state space models are estimated by means of the quasi maximum likelihood approach (cf. Hamilton 1994). Next we describe the estimation results from the full sample analysis. Then we conduct estimation of the favored full sample models in two subsamples and present the obtained empirical evidence. Finally, we analyze in detail the relationship between the extracted (filtered) common factors and important macroeconomic variables in order to provide factor interpretation.

\subsection{Full sample estimation results}

The benchmark model with a single common and eight individual factors is compared to a set of models with two common and several (either eight, six or three) idiosyncratic factors. For the settings with six and three individual factors non-zero loadings are assigned to metals with the largest residual autocorrelation. Moreover, as it is advocated by the AIC and BIC, we impose zero restrictions on common factor loadings such that the first factor refers only to the non-ferrous and the second one only to the precious metals. These restrictions are set by analyzing the structure of the correlation matrix in Table 2. Moreover, they can be justified economically (as in Vansteenkiste 2009). The estimation results for these four specifications are reported in Table 3 .

[Table 3 about here.]

The model with a single common factor is characterized by significant common factor loadings and mainly succeeds (with the exception of silver) in removing residual autocorrelation. However, almost all individual factor $\mathrm{AR}(1)$ coefficients and the majority of individual factor loadings appear to be insignificant. Introducing the second common factor leads to a substantial increase in the log-likelihood function. Although all models exhibit the same autoregressive dynamics for the first (colored) common factor $\left(\hat{\phi}_{1} \approx 0.47\right)$, there is a quite different dynamics of the second (precious) factor with the $\operatorname{AR}(1)$ coefficient $\hat{\phi}_{2} \approx 0.3$. This evidence indicates that the persistence of the second factor is much lower than of the first one. 
The common factor loadings are significant for all metal series in the two factor models. As expected, the introduction of eight individual factors in addition to two common factors completely removes residual autocorrelation, but provides mostly insignificant individual factor loadings as well as insignificant individual factor $\operatorname{AR}(1)$ coefficients. The model with six individual factors (i.e., two common and six individual) allows to remove autocorrelation, but some parameters are still insignificant. The parameters of the model with three individuals factors (i.e., two common and three individual) are mostly significant; moreover, this specification is advocated by both AIC and BIC. However, there remains substantial residual autocorrelation for tin, lead and copper. As it is difficult to favor the uniformly superior specification, we consider in the subsample analysis models with two common and either six or three individuals factors.

The Kalman filter approach is further applied for extracting (filtering) zero-restricted common factors which are related to the non-ferrous and precious metals, respectively. The time evolution and the autocorrelation plots of two common factors for the model with three individual factors is presented in Figure 2. Differences in the autocorrelation plots justify the distinct dynamics of the first and second common factors. Later in Section 4.3 we analyze correlation between the filtered common factors and macroeconomic variables.

[Figure 2 about here.]

Introducing individual factors appears to be mostly important for aluminum and platinum, which is not a surprise because these metals show rather distinct autoregressive dynamics compared to the other metals in their groups as can be observed in Figure 1. The economic reasons for such behavior of aluminium and platinum are quite different. The demand for aluminium increased during the 20th century due to technological developments: because of its light weight it is applied in a variety of industrial uses like construction and cars. Furthermore, the intensive use of aluminum in can production started in the late 1950s. Alternatively, platinum is rather seldom and is not really used for investment purposes as much as gold and silver are (Sari et al. 2010). 


\subsection{Robustness check: subsample analysis}

In order to investigate the stability of our results we conduct a subsample analysis. For this purpose, we divide the full sample in two roughly 50-years subperiods, namely the first part from 1910 till 1959 and the second part from 1960 till 2011. This division is motivated by the history of the 20th century: the first subperiod characterized by both the World Wars and severe economic crises (e.g., the Great Depression) is contrasted to the second peaceful period with a substantial increase of international trade due to globalization. Next we compare the subsample estimates for the single common factor benchmark model with those for a pair of two zero-restricted common factor models with either six or three individual factors. The estimation results are reported in Table 4.

[Table 4 about here.]

Our empirical findings are rather different in the considered subsamples. In the first subperiod, the single common factor model appears to be quite close to the models with two common factors according to both the log-likelihood and AIC/BIC. However, the single factor model is the worst one in the second subperiod, so that the specifications with two common factors should be clearly preferred. This result is in line with the evidence that the autoregressive dynamics of both common factors is very similar to those for the single factor model in the first period. The second subperiod, however, is characterized by quite distinct autoregressive coefficients for both common factors, which are similar to those from the full sample (see Table 3). The AR(1) coefficient for the second common factor which is related to the precious metals is much lower compared to the coefficients for the colored metal factor. There are also remarkable changes in the second common factor loadings: they increase uniformly and significantly in the second subsample which can be interpreted as an increase of volatility in the factor impact. On the contrary, the factor loadings for the first common factor remain rather stable over time. The changing dynamics of the second (precious) metals factor may be attributed to changes in the world currency system. The role of precious metals in the global economy, especially of gold, dramatically decreased after the breakdown of the Bretton-Woods currency system by moving to floating exchange rates (cf. Chen 2010, Baur and Tran 2014). 
Thus, we find that the degree of synchronization (co-movement) in metal prices clearly decreases in the second part of the sample, which is illustrated by increasing significance of the second common as well as of individual factors. In order to understand this phenomenon, recall that the first part of the 20th century was characterized by huge perturbations (such as the World Wars and the Great Depression), whereas the degree of globalization and the strength of international economic linkages remarkably increased during the calm second part of the century (cf. Radetzki 2006). Since correlations are usually much lower in calm time periods on financial markets, our evidence underscores the necessity of introducing additional factors for modeling dynamics of metal series for the last 50 years.

Summarizing the findings from the subsample analysis, we document that the single common factor model is quite good in the first part of the sample, which is characterized by turbulent economic and political developments. However, the second common factor is required for describing dynamics in the second part of the sample which is much more calm and peaceful compared to the first subperiod. The dynamics of the first common factor attributed to the non-ferrous metals remains stable over time, whereas the dynamics of the precious common factor has changed in the second subperiod primarily because of changes in the world currency system.

\subsection{Common factors and macroeconomic variables}

Commodity prices are known to be correlated to the major macroeconomic fundamentals like e.g. industrial production, oil prices, interest rates (cf. Pindyck and Rotemberg 1990). Studying the relation between macroeconomic fundamentals and the extracted common factors is of essential importance for the factor interpretation (cf. Frankel 2008). For this purpose we calculate the correlations of the common factor(s) with a number of important macroeconomic series, namely with industrial production (ip), Standard \& Poor's 500 index (sp500), oil price (oil), consumer price index (cpi) and the real interest rate (int). We report correlations between these macro variables and the common factor(s) extracted from the approaches characterized by the single common with eight individual and two common with three individual factors. 
The evidence from two factor models with eight and six individual factors appears to be very similar. The correlation coefficients for both full sample and subsamples are presented in Table 5.

[Table 5 about here.]

As it is found in the earlier studies (see, e.g., Labys et al. 1999), the full sample correlations of the single common factor with the U.S. ip, oil, sp500 and cpi are significantly positive, whereas they are significantly negative with the interest rates. These significance and sign results appear to be mainly valid for two common factors as well. However, the second common factor related to the precious metals is almost uncorrelated to industrial production and only weakly correlated to sp500.

The difference between the single common and two common factor models are more pronounced in the subsample analysis. In particular, oil is weekly negatively uncorrelated to the common factors in the first subperiod. Concerning the second period, we observe that SP500 is almost uncorrelated to the single and to the second common factors. Moreover, the U.S. industrial production is insignificantly correlated to the common factor(s). However, the OECD industrial production which is a more broad indicator for the worldwide economic activity is significantly positively correlated with the single and the first common factors. Relying on the obtained results in the second part of the sample, we conclude that the first common factor is closer related to the real economy (OECD industrial production, sp500), whereas the second factor is much less correlated with these variables and seems to be a good proxy for the monetary indicators such as cpi. The two common (real and nominal) factors are highly correlated to each other in all models and subsamples, which is in line with economic theory arguments that aggregate output and price level should be positively correlated (cf. Lucas and Sargent 1979).

\section{Summary}

In this paper, we model dynamics of 100 years long monthly time series of eight non-ferrous and precious metals. For this purpose, we suggest state space representations with two common and a number of indi- 
vidual factors, which are compared to the single common factor models used in the current literature. The two common factors are assigned to the groups of non-ferrous and precious metals such that they can be interpreted as representing the real and the nominal sides of the economy, respectively. The usefulness of the second common factor is mostly pronounced in the second part of the 20th century, which is characterized by the increase of international trade and changes in the world currency system.

\section{References}

[1] Agbeyegbe, T.D., 1992. Common Stochastic Trends: Evidence from the London Metal Exchange. Bulletin of Economic Research 44(2): 141-151.

[2] Akram, Q.F., 2009. Commodity Prices, Interest Rates and the Dollar. Energy Economics 31(6): 838-851.

[3] American Metal Market, various years. Metal statistics. Somerset, New Jersey.

[4] Arango, L.E., Arias, F., Florez, A., 2012. Determinants of commodity prices. Applied Economics 44(2): 135-145.

[5] Arezki, R., Loungani, P., van der Ploeg, R., Venables, A.J., 2014. Understanding international commodity price fluctuations. Journal of International Money and Finance 42(C): 1-8.

[6] Batten, J.A., Ciner, C., Lucey, B.M., 2010. The Macroeconomic Determinants of Volatility in Precious Metals Market. Resources Policy 35(2): 65-71.

[7] Baur, D.G., McDermott, T.K., 2010. Is gold a safe haven? International evidence. Journal of Banking and Finance 34(8): 1886-1898.

[8] Baur, D.G., Tran, D.T., 2014. The long-run relationship of gold and silver and the influence of bubbles and financial crisis. Empirical Economics. Advance online publication. Doi: 10.1007/s00181-013-0787-1.

[9] Belke, A., Bordon, I.G., Hendricks, T.W., 2010. Global liquidity and commodity prices - a cointegrated VAR approach for OECD countries. Applied Financial Economics 20(3): 227-242.

[10] Belke, A., Bordon, I.G., Volz, U., 2013. Effects of Global Liquidity on Commodity and Food Prices. World Development 44(C): 31-43.

[11] Bernanke, B.S., Boivin, J., Eliasz, P., 2005. Measuring the Effect of Monetary Policy: A Factor-augmented Vector Autoregressive (FAVAR) Approach. The Quarterly Journal of Economics 120(1): 387-422.

[12] Byrne, J.P., Fazio, G., Fiess, N., 2013. Primary commodity prices: co-movements, common factors and fundamentals. Journal of Development Economics 101: 16-26.

[13] Cashin, P., McDermott, C.J., Scott, A., 2002. Booms and Slumps in World Commodity Prices. Journal of Development Economics 69(1): 277-296.

[14] Cashin, P., McDermott, C.J., 2002. The Long-Run Behavior of Commodity Prices: Small Trends and Big Variability. IMF Working Paper WP/01/68: 1-27.

[15] Chen, M-H., 2010. Understanding world metal prices - Returns, volatility and diversification. Resources Policy $35(3): 127-140$.

[16] Deaton, A., Laroque, G., 1992. On the Behaviour of Commodity Prices. Review of Economic Studies 59(1): 1-23. 
[17] Engineering \& Mining Journal (E\&MJ), various years. MacLean Hunter, Chicago.

[18] Erten, B., Ocampo, A., 2013. Super Cycles of Commodity Prices Since the Mid-Nineteenth Century. World Development 44: 14-30.

[19] Frankel, J.A., 1986. Expectations and Commodity Price Dynamics: The Overshooting Model. American Journal of Agricultural Economics 68(2): 344-348.

[20] Frankel, J.A., 2008. The Effect of Monetary Policy on Real Commodity Prices. In: Campbell J. (Ed.), Asset prices and monetary policy. NBER Books, Cambridge, pp. 291-û333.

[21] Hamilton, J.D., 1994. Time Series Analysis. Princeton University Press, New Jersey.

[22] Hammoudeh, S., Yuan, Y.,2008. Metal Volatility in Presence of Oil and Interest Rate Shocks. Energy Economics 30(2): 606-620.

[23] Hammoudeh, S., Malik, F., McAleer, M., 2011. Risk Management of Precious Metals. The Quarterly Review of Economics and Finance 51(4): 435-441.

[24] Humphreys, D., 2010. The great metals boom: A retrospective. Resources Policy 35(1): 1-13.

[25] Issler, J.V., Rodrigues, C., Burjack, R., 2014. Using common features to understand the behavior of metalcommodity prices and forecast them at different horizons. Journal of International Money and Finance 42: 310335.

[26] Jerrett, D., Cuddington, J.T., 2008. Broadening the Statistical Search for Metal Price Super Cycles to Steel and Related Metals. Resources Policy 33(4): 188-195.

[27] Kose, A., Otrok, C., Whiteman, C.H., 2004. International Business Cycles: World, Region, and Country-specific Factors. The American Economic Review 93(4): 1216-1239.

[28] Labys, W.C., Achouch, A., Terraza, M., 1999. Metal Prices and the Business Cycle. Resources Policy 25(4): $229-238$.

[29] Lombardi, M.J., Osbat, C., Schnatz, B., 2012. Global Commodity Cycles and Linkages: A FAVAR Approach. Empirical Economics 43(2): 651-670.

[30] Lucas, R.E., Sargent, T.J., 1979. After Keynesian Macroeconomics. In: Lucas, R.E., Sargent, T.J. (Eds.), Rational Expectations and Econometric Practice. George Allen \& Unwin, London, pp. 295-320.

[31] Miron, J.A., Romer, C.D., 1990. A New Monthly Index of Industrial Production, 1884-1940. Journal of Economic History 50(2): 321-337.

[32] Pindyck, R.S., Rotemberg, J.J., 1990. The Excess Co-movement of Commodity Prices. The Economic Journal 100(403): 1173-1189.

[33] Qiang, Y., Weber, E.J., 1995. Forecasting World Metal Prices. Discussion paper 95.17, University of Western Australia, Department of Economics.

[34] Qiang, Y., 1998. World Metal Prices: A Database. Discussion paper 98.03, University of Western Australia, Department of Economics.

[35] Radetzki, M., 2006. The Anatomy of Three Commodity Booms. Resources Policy 31(1): 56-64.

[36] Roberts, M.C., 2009. Duration and characteristics of metal price cycles. Resources Policy 34(3): 87-102.

[37] Sari, R., Hammoudeh, S., Soytas, U., 2010. Dynamics of oil price, precious metal prices, and exchange rate. Energy Economics 32(2): 351-362. 
[38] Soytas, U., Sari, R., Hammoudeh, S., Hacihasanoglu, E., 2009. World oil prices, precious metal prices and maroeconomy in Turkey. Energy Policy 37(12): 5557-5566.

[39] U.S. Geological Survey, various years. Minerals Yearbook, Volume I: Metals and Minerals. United States Government Printing Office, Washington, DC.

[40] Vansteenkiste, I., 2009. How important are common factors in driving non-fuel commodity prices? A dynamic factor analysis. ECB Working Paper 1072.

[41] Warren, G.F., Pearson, F.A., Stoker, H.M., 1932. Wholesale prices for 213 years, 1720 to 1932. Ithaca, New York. 
Table 1: Descriptive statistics for metals and macro variables

\begin{tabular}{|c|c|c|c|c|c|c|c|}
\hline & $\min$ & $\max$ & skewness & kurtosis & $\begin{array}{c}\text { Jarque-Bera } \\
\text { statistic }\end{array}$ & $\begin{array}{l}\text { ADF-test } \\
\text { statistic }\end{array}$ & $\begin{array}{c}\text { ARCH-test } \\
\text { statistic }\end{array}$ \\
\hline $\operatorname{tin}$ & -7.4602 & 7.9168 & 0.0279 & 11.6615 & 3823.13 & $\begin{array}{c}-22.077 \\
(0.00)\end{array}$ & $\begin{array}{c}173.320 \\
(0.00)\end{array}$ \\
\hline zinc & -6.0219 & 5.7222 & 0.0726 & 8.7551 & 1688.89 & $\begin{array}{c}-20.441 \\
(0.00)\end{array}$ & $\begin{array}{c}104.085 \\
(0.00)\end{array}$ \\
\hline lead & -4.3889 & 12.1879 & 1.2780 & 23.1618 & 21047.40 & $\begin{array}{c}-13.882 \\
(0.00)\end{array}$ & $\begin{array}{c}59.647 \\
(0.00)\end{array}$ \\
\hline copper & -5.5402 & 12.2390 & 1.1793 & 24.3148 & 23434.82 & $\begin{array}{c}-20.502 \\
(0.00)\end{array}$ & $\begin{array}{l}5.158 \\
(0.02)\end{array}$ \\
\hline aluminum & -7.8398 & 7.5620 & 0.1537 & 14.0035 & 6174.71 & $\begin{array}{c}-21.213 \\
(0.00)\end{array}$ & $\begin{array}{c}20.961 \\
(0.00)\end{array}$ \\
\hline gold & -8.4429 & 9.5634 & 0.9128 & 21.2767 & 17191.85 & $\begin{array}{c}-23.156 \\
(0.00)\end{array}$ & $\begin{array}{c}99.778 \\
(0.00)\end{array}$ \\
\hline silver & -8.1177 & 9.0625 & 0.6309 & 17.7647 & 11189.86 & $\begin{array}{c}-18.823 \\
(0.00)\end{array}$ & $\begin{array}{c}158.999 \\
(0.00)\end{array}$ \\
\hline platinum & -6.1670 & 7.2429 & 1.0063 & 14.1207 & 6508.39 & $\begin{array}{c}-22.555 \\
(0.00)\end{array}$ & $\begin{array}{c}49.539 \\
(0.00) \\
\end{array}$ \\
\hline ip & -5.3725 & 4.3840 & -0.3972 & 6.6772 & 721.21 & $\begin{array}{c}-8.472 \\
(0.00)\end{array}$ & $\begin{array}{c}212.247 \\
(0.00)\end{array}$ \\
\hline oil & -8.3883 & 11.6918 & 0.9747 & 33.5646 & 47798.75 & $\begin{array}{c}-23.889 \\
(0.00)\end{array}$ & $\begin{array}{l}1.603 \\
(0.20)\end{array}$ \\
\hline sp500 & -7.0450 & 6.2405 & -0.6322 & 10.9625 & 3312.26 & $\begin{array}{c}-23.966 \\
(0.00)\end{array}$ & $\begin{array}{c}82.208 \\
(0.00)\end{array}$ \\
\hline cpi & -4.9961 & 7.7583 & 0.3570 & 10.6180 & 2983.26 & $\begin{array}{c}-9.093 \\
(0.00)\end{array}$ & $\begin{array}{c}30.109 \\
(0.00)\end{array}$ \\
\hline int & -6.9972 & 5.8202 & 0.0833 & 11.5701 & 3744.13 & $\begin{array}{c}-12.985 \\
(0.00)\end{array}$ & $\begin{array}{c}26.037 \\
(0.00)\end{array}$ \\
\hline
\end{tabular}

Note: Standardized log differences; number of lags for the ADF-test is chosen via BIC and varies between 1 and 12 , all models include a constant term; $p$-values in parenthesis. ip: U.S. industrial production index, oil: crude oil price, sp500: S\&P 500 index, cpi: consumer price index, int: real interest rate. 
Table 2: Correlation analysis of macroeconomic fundamentals and metal price series

\begin{tabular}{|c|c|c|c|c|c|c|c|c|c|c|c|c|c|}
\hline & $\operatorname{tin}$ & zinc & lead & copper & aluminum & gold & silver & platinum & ip & oil & sp500 & cpi & int \\
\hline $\operatorname{tin}$ & & $\begin{array}{c}0.289 \\
(0.00)\end{array}$ & $\begin{array}{l}0.320 \\
(0.00)\end{array}$ & $\begin{array}{l}0.295 \\
(0.00)\end{array}$ & $\begin{array}{l}0.199 \\
(0.00)\end{array}$ & $\begin{array}{c}0.051 \\
(0.07)\end{array}$ & $\begin{array}{l}0.195 \\
(0.00)\end{array}$ & $\begin{array}{c}0.145 \\
(0.00)\end{array}$ & $\begin{array}{l}0.086 \\
(0.00)\end{array}$ & $\begin{array}{c}0.129 \\
(0.00)\end{array}$ & $\begin{array}{c}0.126 \\
(0.00)\end{array}$ & $\begin{array}{c}0.113 \\
(0.00)\end{array}$ & $\begin{array}{c}-0.106 \\
(0.00)\end{array}$ \\
\hline zinc & $\begin{array}{c}0.289 \\
(0.00)\end{array}$ & & $\begin{array}{c}0.446 \\
(0.00)\end{array}$ & $\begin{array}{l}0.458 \\
(0.00)\end{array}$ & $\begin{array}{l}0.348 \\
(0.00)\end{array}$ & $\begin{array}{c}0.073 \\
(0.01)\end{array}$ & $\begin{array}{l}0.203 \\
(0.009\end{array}$ & $\begin{array}{c}0.229 \\
(0.00)\end{array}$ & $\begin{array}{c}0.155 \\
(0.00)\end{array}$ & $\begin{array}{c}0.053 \\
(0.06)\end{array}$ & $\begin{array}{c}0.134 \\
(0.00)\end{array}$ & $\begin{array}{c}0.115 \\
(0.00)\end{array}$ & $\begin{array}{c}-0.116 \\
(0.00)\end{array}$ \\
\hline lead & $\begin{array}{c}0.320 \\
(0.00)\end{array}$ & $\begin{array}{c}0.446 \\
(0.00)\end{array}$ & & $\begin{array}{c}0.532 \\
(0.00)\end{array}$ & $\begin{array}{c}0.282 \\
(0.00)\end{array}$ & $\begin{array}{c}0.141 \\
(0.00)\end{array}$ & $\begin{array}{c}0.230 \\
(0.00)\end{array}$ & $\begin{array}{c}0.176 \\
(0.00)\end{array}$ & $\begin{array}{c}0.102 \\
(0.00)\end{array}$ & $\begin{array}{l}0.098 \\
(0.00)\end{array}$ & $\begin{array}{c}0.096 \\
(0.00)\end{array}$ & $\begin{array}{c}0.109 \\
(0.00)\end{array}$ & $\begin{array}{c}-0.109 \\
(0.00)\end{array}$ \\
\hline copper & $\begin{array}{c}0.295 \\
(0.00)\end{array}$ & $\begin{array}{c}0.458 \\
(0.00)\end{array}$ & $\begin{array}{c}0.532 \\
(0.00)\end{array}$ & & $\begin{array}{c}0.323 \\
(0.00)\end{array}$ & $\begin{array}{c}0.193 \\
(0.00)\end{array}$ & $\begin{array}{c}0.263 \\
(0.00)\end{array}$ & $\begin{array}{c}0.215 \\
(0.00)\end{array}$ & $\begin{array}{c}0.126 \\
(0.00)\end{array}$ & $\begin{array}{c}0.095 \\
(0.00)\end{array}$ & $\begin{array}{c}0.119 \\
(0.00)\end{array}$ & $\begin{array}{c}0.101 \\
(0.00)\end{array}$ & $\begin{array}{c}-0.104 \\
(0.00)\end{array}$ \\
\hline aluminum & $\begin{array}{c}0.199 \\
(0.00) \\
\end{array}$ & $\begin{array}{c}0.348 \\
(0.00) \\
\end{array}$ & $\begin{array}{c}0.282 \\
(0.00) \\
\end{array}$ & $\begin{array}{c}0.323 \\
(0.00) \\
\end{array}$ & & $\begin{array}{c}0.087 \\
(0.00) \\
\end{array}$ & $\begin{array}{c}0.190 \\
(0.00) \\
\end{array}$ & $\begin{array}{l}0.236 \\
(0.00) \\
\end{array}$ & $\begin{array}{c}0.056 \\
(0.05) \\
\end{array}$ & $\begin{array}{c}0.122 \\
(0.00) \\
\end{array}$ & $\begin{array}{c}0.034 \\
(0.23) \\
\end{array}$ & $\begin{array}{c}0.068 \\
(0.02)\end{array}$ & $\begin{array}{c}-0.041 \\
(0.15) \\
\end{array}$ \\
\hline gold & $\begin{array}{c}0.051 \\
(0.07)\end{array}$ & $\begin{array}{c}0.073 \\
(0.01)\end{array}$ & $\begin{array}{c}0.141 \\
(0.00)\end{array}$ & $\begin{array}{l}0.193 \\
(0.00)\end{array}$ & $\begin{array}{l}0.087 \\
(0.00)\end{array}$ & & $\begin{array}{l}0.521 \\
(0.00)\end{array}$ & $\begin{array}{l}0.297 \\
(0.00)\end{array}$ & $\begin{array}{c}-0.007 \\
(0.80)\end{array}$ & $\begin{array}{c}0.130 \\
(0.00)\end{array}$ & $\begin{array}{c}-0.013 \\
(0.64)\end{array}$ & $\begin{array}{c}0.032 \\
(0.27)\end{array}$ & $\begin{array}{c}-0.043 \\
(0.13)\end{array}$ \\
\hline silver & $\begin{array}{c}0.195 \\
(0.00)\end{array}$ & $\begin{array}{c}0.203 \\
(0.00)\end{array}$ & $\begin{array}{c}0.230 \\
(0.00)\end{array}$ & $\begin{array}{l}0.263 \\
(0.00)\end{array}$ & $\begin{array}{c}0.190 \\
(0.00)\end{array}$ & $\begin{array}{c}0.521 \\
(0.00)\end{array}$ & & $\begin{array}{l}0.388 \\
(0.00)\end{array}$ & $\begin{array}{l}0.035 \\
(0.22)\end{array}$ & $\begin{array}{c}0.141 \\
(0.00)\end{array}$ & $\begin{array}{c}0.052 \\
(0.07)\end{array}$ & $\begin{array}{c}0.111 \\
(0.00)\end{array}$ & $\begin{array}{c}-0.079 \\
(0.00)\end{array}$ \\
\hline platinum & $\begin{array}{c}0.145 \\
(0.00)\end{array}$ & $\begin{array}{c}0.229 \\
(0.00)\end{array}$ & $\begin{array}{c}0.176 \\
(0.00)\end{array}$ & $\begin{array}{c}0.215 \\
(0.00)\end{array}$ & $\begin{array}{c}0.236 \\
(0.00)\end{array}$ & $\begin{array}{c}0.297 \\
(0.00)\end{array}$ & $\begin{array}{c}0.388 \\
(0.00)\end{array}$ & & $\begin{array}{c}0.059 \\
(0.04)\end{array}$ & $\begin{array}{c}0.051 \\
(0.07)\end{array}$ & $\begin{array}{c}0.058 \\
(0.04)\end{array}$ & $\begin{array}{c}0.095 \\
(0.00)\end{array}$ & $\begin{array}{c}-0.071 \\
(0.01)\end{array}$ \\
\hline ip & $\begin{array}{c}0.086 \\
(0.00)\end{array}$ & $\begin{array}{c}0.155 \\
(0.00)\end{array}$ & $\begin{array}{c}0.102 \\
(0.00)\end{array}$ & $\begin{array}{c}0.126 \\
(0.00)\end{array}$ & $\begin{array}{l}0.056 \\
(0.05)\end{array}$ & $\begin{array}{c}-0.007 \\
(0.80)\end{array}$ & $\begin{array}{l}0.035 \\
(0.22)\end{array}$ & $\begin{array}{l}0.059 \\
(0.04)\end{array}$ & & $\begin{array}{c}-0.003 \\
(0.91)\end{array}$ & $\begin{array}{c}0.041 \\
(0.15)\end{array}$ & $\begin{array}{c}0.043 \\
(0.13)\end{array}$ & $\begin{array}{c}-0.096 \\
(0.00)\end{array}$ \\
\hline oil & $\begin{array}{c}0.129 \\
(0.00)\end{array}$ & $\begin{array}{c}0.053 \\
(0.06)\end{array}$ & $\begin{array}{l}0.098 \\
(0.00)\end{array}$ & $\begin{array}{c}0.095 \\
(0.00)\end{array}$ & $\begin{array}{l}0.122 \\
(0.00)\end{array}$ & $\begin{array}{c}0.130 \\
(0.00)\end{array}$ & $\begin{array}{l}0.141 \\
(0.00)\end{array}$ & $\begin{array}{l}0.051 \\
(0.07)\end{array}$ & $\begin{array}{c}-0.003 \\
(0.91)\end{array}$ & & $\begin{array}{c}-0.006 \\
(0.82)\end{array}$ & $\begin{array}{c}0.159 \\
(0.00)\end{array}$ & $\begin{array}{c}-0.022 \\
(0.43)\end{array}$ \\
\hline sp500 & $\begin{array}{c}0.126 \\
(0.00)\end{array}$ & $\begin{array}{c}0.134 \\
(0.00)\end{array}$ & $\begin{array}{c}0.096 \\
(0.00)\end{array}$ & $\begin{array}{c}0.119 \\
(0.00)\end{array}$ & $\begin{array}{l}0.034 \\
(0.23)\end{array}$ & $\begin{array}{c}-0.013 \\
(0.64)\end{array}$ & $\begin{array}{c}0.052 \\
(0.07)\end{array}$ & $\begin{array}{l}0.058 \\
(0.04)\end{array}$ & $\begin{array}{l}0.041 \\
(0.15)\end{array}$ & $\begin{array}{c}-0.006 \\
(0.82)\end{array}$ & & $\begin{array}{l}0.009 \\
(0.75)\end{array}$ & $\begin{array}{c}-0.044 \\
(0.12)\end{array}$ \\
\hline cpi & $\begin{array}{c}0.113 \\
(0.00)\end{array}$ & $\begin{array}{c}0.115 \\
(0.00)\end{array}$ & $\begin{array}{c}0.109 \\
(0.00)\end{array}$ & $\begin{array}{c}0.101 \\
(0.00)\end{array}$ & $\begin{array}{l}0.068 \\
(0.02)\end{array}$ & $\begin{array}{c}0.032 \\
(0.27)\end{array}$ & $\begin{array}{c}0.111 \\
(0.00)\end{array}$ & $\begin{array}{l}0.095 \\
(0.00)\end{array}$ & $\begin{array}{c}0.043 \\
(0.13)\end{array}$ & $\begin{array}{c}0.159 \\
(0.00)\end{array}$ & $\begin{array}{c}0.009 \\
(0.75)\end{array}$ & & $\begin{array}{c}-0.602 \\
(0.00)\end{array}$ \\
\hline int & $\begin{array}{c}-0.106 \\
(0.00) \\
\end{array}$ & $\begin{array}{c}-0.116 \\
(0.00) \\
\end{array}$ & $\begin{array}{c}-0.109 \\
(0.00)\end{array}$ & $\begin{array}{c}-0104 \\
(0.00)\end{array}$ & $\begin{array}{c}-0.041 \\
(0.15)\end{array}$ & $\begin{array}{c}-0.043 \\
(0.13)\end{array}$ & $\begin{array}{l}.0 .079 \\
(0.00)\end{array}$ & $\begin{array}{c}-0.071 \\
(0.01)\end{array}$ & $\begin{array}{c}-0.096 \\
(0.00)\end{array}$ & $\begin{array}{c}-0.022 \\
(0.43)\end{array}$ & $\begin{array}{c}-0.044 \\
(0.12)\end{array}$ & $\begin{array}{c}-0.602 \\
(0.00)\end{array}$ & \\
\hline
\end{tabular}

Note: Pearson's correlation coefficients, standardized log differences, $p$-values in parenthesis; ip: U.S. industrial production index, oil: crude oil price, sp500: S\&P 500 index, cpi: consumer price index, int: real interest rate. 
Table 3: Common factor analysis

\begin{tabular}{|c|c|c|c|c|c|c|c|c|c|c|c|}
\hline & \multicolumn{2}{|c|}{1 common +8 individual } & \multicolumn{3}{|c|}{2 common +8 individual } & \multicolumn{3}{|c|}{2 common +6 individual } & \multicolumn{3}{|c|}{2 common +3 individual } \\
\hline \multicolumn{12}{|c|}{ Block A: AR(1) factor dynamics } \\
\hline & $\phi($ std $)$ & $\phi_{i}(\mathrm{std})$ & $\phi_{1}(\mathrm{std})$ & $\phi_{2}(\mathrm{std})$ & $\phi_{i}(\mathrm{std})$ & $\phi_{1}(\mathrm{std})$ & $\phi_{2}($ std $)$ & $\phi_{i}(\mathrm{std})$ & $\phi_{1}(\mathrm{std})$ & $\phi_{2}(\mathrm{std})$ & $\phi_{i}($ std $)$ \\
\hline factor 1 & $\begin{array}{c}0.466^{* * *} \\
(0.09)\end{array}$ & & $\begin{array}{c}0.423^{*} \\
(0.22)\end{array}$ & & & $\begin{array}{c}0.423^{* * * *} \\
(0.03)\end{array}$ & & & $\begin{array}{c}0.461^{* * *} \\
(0.03)\end{array}$ & & \\
\hline factor 2 & & & & $\begin{array}{c}0.283 \\
(0.21)\end{array}$ & & & $\begin{array}{c}0.287^{* * *} \\
(0.03)\end{array}$ & & & $\begin{array}{c}0.288^{* * * *} \\
\quad(0.03)\end{array}$ & \\
\hline$\rho$ & & & & $\begin{array}{l}0.397 \\
(0.28)\end{array}$ & & & $\begin{array}{c}0.429 * * * \\
(0.04)\end{array}$ & & & $\begin{array}{c}0.416^{* * *} \\
(0.03)\end{array}$ & \\
\hline $\operatorname{tin}$ & & $\begin{array}{l}0.247 \\
(0.19)\end{array}$ & & & $\begin{array}{l}0.388 \\
(0.97)\end{array}$ & & & $\begin{array}{l}0.251 \\
(0.97)\end{array}$ & & & \\
\hline zinc & & $\begin{array}{l}0.330 \\
(0.52)\end{array}$ & & & $\begin{array}{l}0.349 \\
(0.67)\end{array}$ & & & $\begin{array}{l}0.307 \\
(0.55)\end{array}$ & & & $\begin{array}{l}0.313 \\
(0.21)\end{array}$ \\
\hline lead & & $\begin{array}{l}0.266 \\
(0.29)\end{array}$ & & & $\begin{array}{l}0.294 \\
(0.57)\end{array}$ & & & $\begin{array}{c}0.307^{* * * *} \\
(0.08)\end{array}$ & & & \\
\hline copper & & $\begin{array}{c}0.301^{*} \\
(0.16)\end{array}$ & & & $\begin{array}{l}0.270 \\
(0.57)\end{array}$ & & & $\begin{array}{c}0.400^{* * * *} \\
(0.12)\end{array}$ & & & \\
\hline aluminum & & $\begin{array}{l}0.420 \\
(0.80)\end{array}$ & & & $\begin{array}{l}0.480 \\
(0.93)\end{array}$ & & & $\begin{array}{c}0.461^{* * * *} \\
(0.05)\end{array}$ & & & $\begin{array}{c}0.302^{* * * *} \\
(0.05)\end{array}$ \\
\hline gold & & $\begin{array}{l}0.194 \\
(0.13)\end{array}$ & & & $\begin{array}{l}0.457 \\
(1.50)\end{array}$ & & & & & & \\
\hline silver & & $\begin{array}{l}0.109 \\
(1.66)\end{array}$ & & & $\begin{array}{l}0.177 \\
(2.10)\end{array}$ & & & & & & \\
\hline platinum & & $\begin{array}{l}0.283 \\
(0.43)\end{array}$ & & & $\begin{array}{l}0.330 \\
(0.60) \\
\end{array}$ & & & $\begin{array}{l}0.350 \\
(0.37)\end{array}$ & & & $\begin{array}{c}0.184^{* * *} \\
(0.06)\end{array}$ \\
\hline \multicolumn{12}{|c|}{ Block B: factor loadings } \\
\hline & $h($ std $)$ & $h_{i}(\mathrm{std})$ & $h_{1}(\mathrm{std})$ & $h_{2}(\mathrm{std})$ & $h_{i}(\mathrm{std})$ & $h_{1}(\mathrm{std})$ & $h_{2}(\mathrm{std})$ & $h_{i}(\mathrm{std})$ & $h_{1}($ std $)$ & $h_{2}($ std $)$ & $h_{i}(\mathrm{std})$ \\
\hline $\operatorname{tin}$ & $\begin{array}{c}0.378^{* * *} \\
(0.04)\end{array}$ & $\begin{array}{c}0.598^{* * *} \\
(0.18)\end{array}$ & $\begin{array}{c}0.385^{* * *} \\
(0.13)\end{array}$ & 0 & $\begin{array}{l}0.446 \\
(0.33)\end{array}$ & $\begin{array}{c}0.391^{* * *} * \\
(0.05)\end{array}$ & 0 & $\begin{array}{c}0.672^{* *} \\
(0.28)\end{array}$ & $\begin{array}{c}0.395^{* * * *} \\
(0.02)\end{array}$ & 0 & \\
\hline zinc & $\begin{array}{c}0.571^{* * *} \\
(0.06)\end{array}$ & $\begin{array}{l}0.708 \\
(0.66)\end{array}$ & $\begin{array}{c}0.585^{* * *} \\
(0.19)\end{array}$ & 0 & $\begin{array}{c}-0.638 \\
(0.76)\end{array}$ & $\begin{array}{c}0.566^{* * *} \\
(0.17)\end{array}$ & 0 & $\begin{array}{c}-0.679 \\
(0.68)\end{array}$ & $\begin{array}{c}0.573^{* * *} \\
(0.03)\end{array}$ & 0 & $\begin{array}{c}0.719^{* *} \\
(0.32)\end{array}$ \\
\hline lead & $\begin{array}{c}0.607^{* * *} \\
(0.10)\end{array}$ & $\begin{array}{l}0.560 \\
(0.44)\end{array}$ & $\begin{array}{c}0.671^{* * *} \\
(0.10)\end{array}$ & 0 & $\begin{array}{c}0.443^{* *} \\
(0.20)\end{array}$ & $\begin{array}{c}0.625^{* * *} \\
(0.07)\end{array}$ & 0 & $\begin{array}{c}0.515^{* * *} \\
(0.07)\end{array}$ & $\begin{array}{c}0.611^{* * * *} \\
(0.04)\end{array}$ & 0 & \\
\hline copper & $\begin{array}{c}0.613^{* * *} \\
(0.09)\end{array}$ & $\begin{array}{c}-0.516^{* * *} \\
(0.15)\end{array}$ & $\begin{array}{c}0.671^{* *} \\
(0.29)\end{array}$ & 0 & $\begin{array}{c}0.524^{*} \\
(0.31)\end{array}$ & $\begin{array}{c}0.662^{* * *} \\
(0.12)\end{array}$ & 0 & $\begin{array}{c}-0.441^{* * *} \\
(0.07)\end{array}$ & $\begin{array}{c}0.646^{* * *} \\
(0.03)\end{array}$ & 0 & \\
\hline aluminum & $\begin{array}{c}0.419^{* * * *} \\
(0.12)\end{array}$ & $\begin{array}{l}0.630 \\
(0.84)\end{array}$ & $\begin{array}{c}0.415^{* *} \\
(0.19)\end{array}$ & 0 & $\begin{array}{l}0.574 \\
(0.99)\end{array}$ & $\begin{array}{c}0.413^{* * *} \\
(0.08)\end{array}$ & 0 & $\begin{array}{c}-0.581^{* * *} \\
(0.04)\end{array}$ & $\begin{array}{c}0.417^{* * * *} \\
(0.02)\end{array}$ & 0 & $\begin{array}{c}0.814^{* * *} \\
(0.07)\end{array}$ \\
\hline gold & $\begin{array}{c}0.275^{* * *} \\
(0.02)\end{array}$ & $\begin{array}{c}0.610^{* *} \\
(0.26)\end{array}$ & 0 & $\begin{array}{c}0.595^{* * *} \\
(0.11)\end{array}$ & $\begin{array}{l}0.249 \\
(0.46)\end{array}$ & 0 & $\begin{array}{c}0.560^{* * *} \\
(0.03)\end{array}$ & & 0 & $\begin{array}{c}0.586^{* * *} \\
(0.02)\end{array}$ & \\
\hline silver & $\begin{array}{c}0.408^{* * *} * \\
(0.10)\end{array}$ & $\begin{array}{l}0.009 \\
(0.27)\end{array}$ & 0 & $\begin{array}{c}0.790^{* * * *} \\
(0.16)\end{array}$ & $\begin{array}{l}0.254 \\
(0.65)\end{array}$ & 0 & $\begin{array}{c}0.781^{* * *} * \\
(0.05)\end{array}$ & & 0 & $\begin{array}{c}0.794^{* * * *} \\
(0.03)\end{array}$ & \\
\hline platinum & $\begin{array}{c}0.347^{* * *} * \\
(0.08)\end{array}$ & $\begin{array}{c}0.711 \\
(0.66)\end{array}$ & 0 & $\begin{array}{c}0.454^{* * *} \\
(0.09)\end{array}$ & $\begin{array}{l}0.613 \\
(0.75) \\
\end{array}$ & 0 & $\begin{array}{c}0.438^{* * *} \\
(0.09)\end{array}$ & $\begin{array}{c}0.548^{*} \\
(0.32)\end{array}$ & 0 & $\begin{array}{c}0.454^{* * * *} \\
(0.03)\end{array}$ & $\begin{array}{c}-0.833^{* * * *} \\
(0.13)\end{array}$ \\
\hline \multicolumn{12}{|c|}{ Block C: residual autocorrelations } \\
\hline $\operatorname{tin}$ & & & & 0.03 & & & 0.00 & & & $0.13^{* * *}$ & \\
\hline $\operatorname{zinc}$ & & & & $0.06^{* *}$ & & & $0.05^{*}$ & & & 0.04 & \\
\hline lead & & & & $0.06^{* *}$ & & & 0.02 & & & $0.16^{* * *}$ & \\
\hline copper & & & & 0.03 & & & 0.00 & & & $0.15^{* * *}$ & \\
\hline aluminum & & & & 0.02 & & & 0.02 & & & -0.01 & \\
\hline gold & & & & 0.01 & & & $0.06^{* *}$ & & & $0.06^{* *}$ & \\
\hline silver & & $* * *$ & & 0.02 & & & 0.04 & & & 0.04 & \\
\hline platinum & & & & 0.02 & & & 0.03 & & & 0.01 & \\
\hline \multicolumn{12}{|c|}{ Block D: Log Likelihoods etc. (diagnostics) } \\
\hline $\log \mathrm{L}$ & & 2.38 & & -7340.90 & & & -7346.66 & & & -7396.56 & \\
\hline $\mathrm{AIC}$ & & & & -17.34 & & & -18.57 & & & -25.91 & \\
\hline $\mathrm{BIC}$ & & & & -17.19 & & & -18.44 & & & -25.81 & \\
\hline
\end{tabular}

Note: standard deviation (std) in parenthesis; * significance at the 0.1 level, $* *$ significance at the 0.05 level, $* * *$ significance at the 0.01 level. 


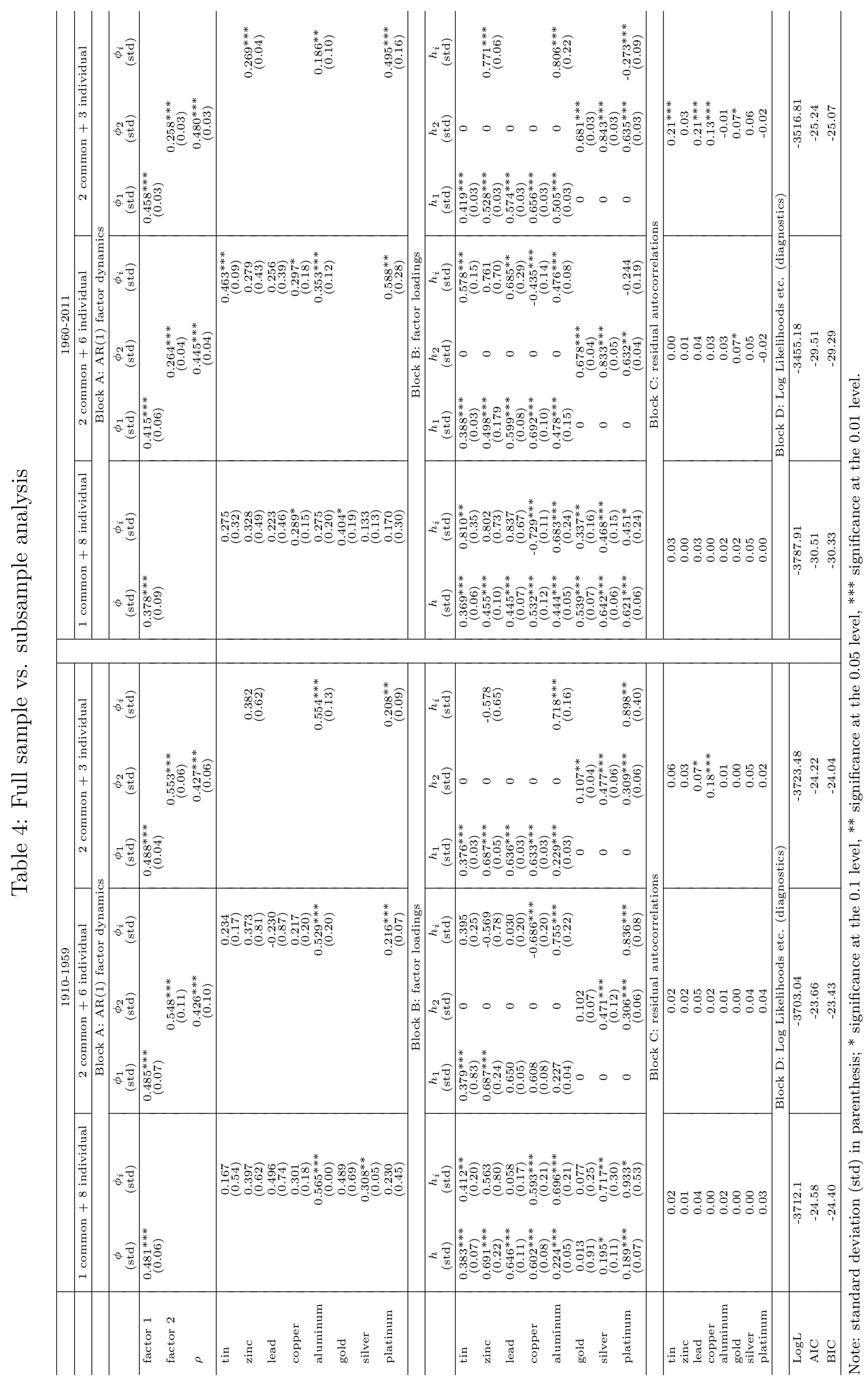


Table 5: Correlation analysis: macroeconomic fundamentals and state variables

\begin{tabular}{|c|c|c|c|c|c|c|c|c|c|}
\hline & \multicolumn{3}{|c|}{ full sample } & \multicolumn{3}{|c|}{ 1910-1959 } & \multicolumn{3}{|c|}{ 1960-2011 } \\
\hline & \multirow{2}{*}{$\begin{array}{c}1 \text { common }+ \\
8 \text { individual } \\
\text { factor }\end{array}$} & \multicolumn{2}{|c|}{$\begin{array}{l}2 \text { common }+ \\
3 \text { individual }\end{array}$} & \multirow{2}{*}{$\begin{array}{c}1 \text { common }+ \\
8 \text { individual } \\
\text { factor }\end{array}$} & \multicolumn{2}{|c|}{$\begin{array}{l}2 \text { common }+ \\
3 \text { individual }\end{array}$} & \multirow{2}{*}{$\begin{array}{c}1 \text { common }+ \\
8 \text { individual } \\
\text { factor }\end{array}$} & \multicolumn{2}{|c|}{$\begin{array}{l}2 \text { common }+ \\
3 \text { individual }\end{array}$} \\
\hline & & factor 1 & factor 2 & & factor 1 & factor 2 & & factor 1 & factor 2 \\
\hline factor 1 & & 1 & $\begin{array}{l}0.508 \\
(0.00)\end{array}$ & & 1 & $\begin{array}{l}0.618 \\
(0.00)\end{array}$ & & 1 & $\begin{array}{l}0.560 \\
(0.00)\end{array}$ \\
\hline factor 2 & & $\begin{array}{l}0.508 \\
(0.00) \\
\end{array}$ & 1 & & $\begin{array}{l}0.618 \\
(0.00) \\
\end{array}$ & 1 & & $\begin{array}{l}0.560 \\
(0.00) \\
\end{array}$ & 1 \\
\hline ip & $\begin{array}{l}0.157 \\
(0.00)\end{array}$ & $\begin{array}{l}0.166 \\
(0.00)\end{array}$ & $\begin{array}{l}0.049 \\
(0.09)\end{array}$ & $\begin{array}{l}0.297 \\
(0.00)\end{array}$ & $\begin{array}{l}0.303 \\
(0.00)\end{array}$ & $\begin{array}{l}0.205 \\
(0.00)\end{array}$ & $\begin{array}{l}0.026 \\
(0.52)\end{array}$ & $\begin{array}{l}0.019 \\
(0.65)\end{array}$ & $\begin{array}{l}0.018 \\
(0.65)\end{array}$ \\
\hline oil & $\begin{array}{l}0.160 \\
(0.00)\end{array}$ & $\begin{array}{l}0.157 \\
(0.00)\end{array}$ & $\begin{array}{l}0.158 \\
(0.00)\end{array}$ & $\begin{array}{c}-0.064 \\
(0.13)\end{array}$ & $\begin{array}{c}-0.066 \\
(0.10)\end{array}$ & $\begin{array}{c}-0.049 \\
(0.23)\end{array}$ & $\begin{array}{l}0.284 \\
(0.00)\end{array}$ & $\begin{array}{l}0.296 \\
(0.00)\end{array}$ & $\begin{array}{l}0.225 \\
(0.00)\end{array}$ \\
\hline sp500 & $\begin{array}{l}0.141 \\
(0.00)\end{array}$ & $\begin{array}{l}0.143 \\
(0.00)\end{array}$ & $\begin{array}{l}0.059 \\
(0.04)\end{array}$ & $\begin{array}{l}0.218 \\
(0.00)\end{array}$ & $\begin{array}{l}0.220 \\
(0.00)\end{array}$ & $\begin{array}{l}0.154 \\
(0.00)\end{array}$ & $\begin{array}{l}0.057 \\
(0.15)\end{array}$ & $\begin{array}{l}0.070 \\
(0.08)\end{array}$ & $\begin{array}{l}0.038 \\
(0.34)\end{array}$ \\
\hline cpi & $\begin{array}{l}0.165 \\
(0.00)\end{array}$ & $\begin{array}{l}0.161 \\
(0.00)\end{array}$ & $\begin{array}{l}0.119 \\
(0.00)\end{array}$ & $\begin{array}{l}0.209 \\
(0.00)\end{array}$ & $\begin{array}{l}0.208 \\
(0.00)\end{array}$ & $\begin{array}{l}0.255 \\
(0.00)\end{array}$ & $\begin{array}{l}0.169 \\
(0.00)\end{array}$ & $\begin{array}{l}0.155 \\
(0.00)\end{array}$ & $\begin{array}{l}0.130 \\
(0.00)\end{array}$ \\
\hline int & $\begin{array}{c}-0.152 \\
(0.00)\end{array}$ & $\begin{array}{c}-0.152 \\
(0.00)\end{array}$ & $\begin{array}{c}-0.092 \\
(0.00)\end{array}$ & $\begin{array}{c}-0.234 \\
(0.00)\end{array}$ & $\begin{array}{c}-0.235 \\
(0.00)\end{array}$ & $\begin{array}{c}-0.257 \\
(0.00)\end{array}$ & $\begin{array}{c}-0.090 \\
(0.03)\end{array}$ & $\begin{array}{c}-0.070 \\
(0.08)\end{array}$ & $\begin{array}{c}-0.076 \\
(0.06)\end{array}$ \\
\hline oecd & & & & & & & $\begin{array}{l}0.185 \\
(0.00)\end{array}$ & $\begin{array}{l}0.285 \\
(0.00)\end{array}$ & $\begin{array}{l}0.062 \\
(0.19)\end{array}$ \\
\hline
\end{tabular}

Note: Pearson's correlation coefficients, $p$-values in parenthesis; ip: U.S. industrial production index, oil: crude oil price, sp500: S\&P 500 index, cpi: consumer price index, int: real interest rate, oecd: OECD industrial production index (only available from 1975 onwards). 
Figure 1: Sample autocorrelation - metal price series

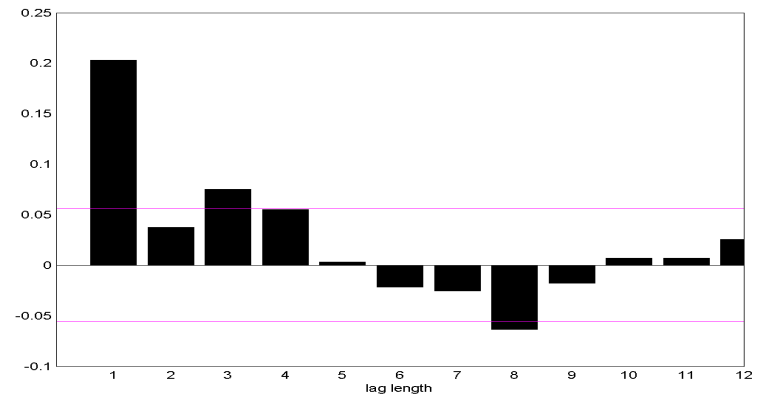

(a) $\operatorname{tin}$

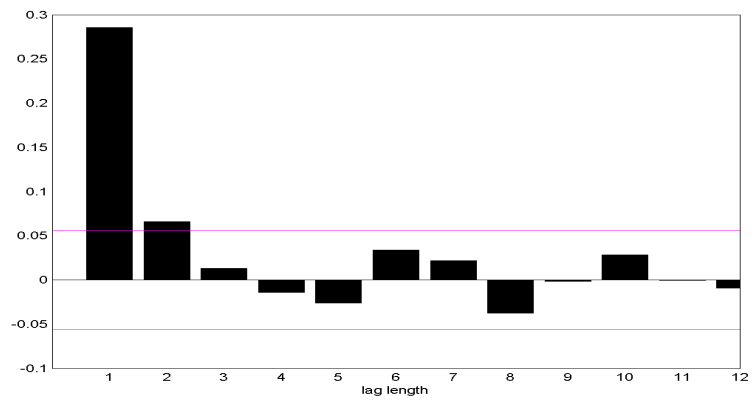

(c) lead

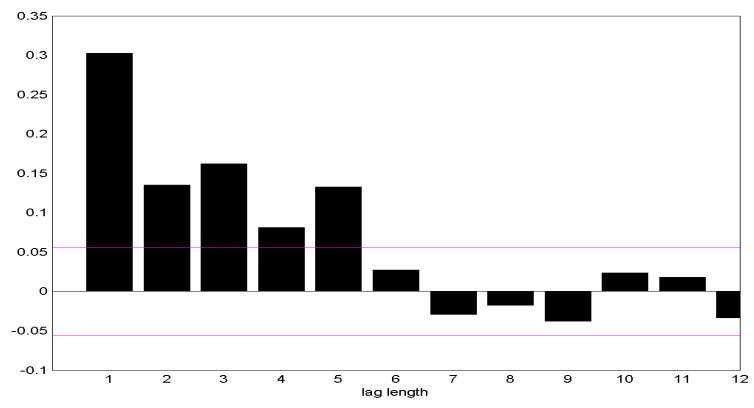

(e) aluminum

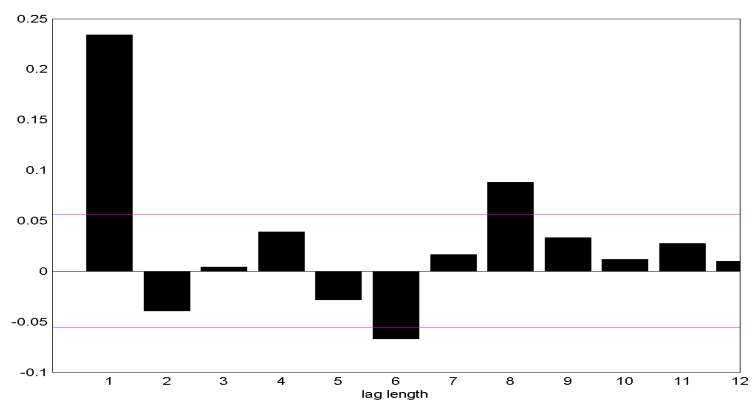

(g) silver

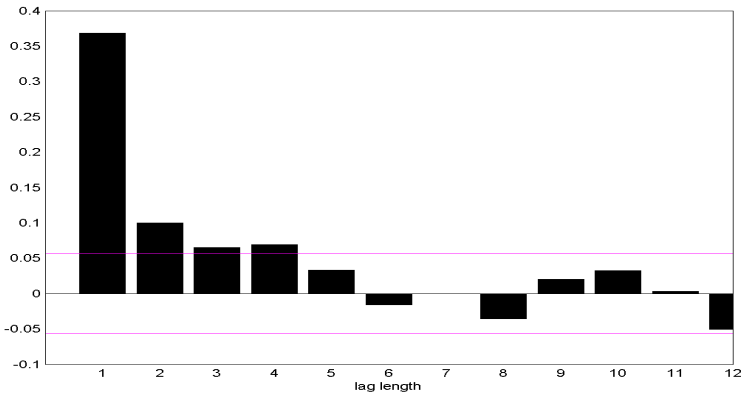

(b) zinc

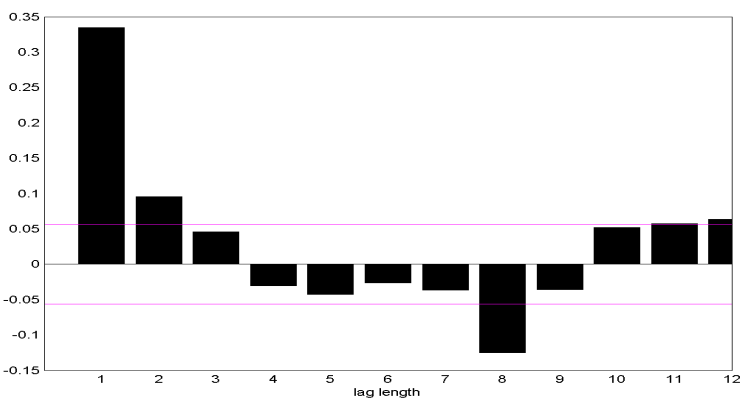

(d) copper

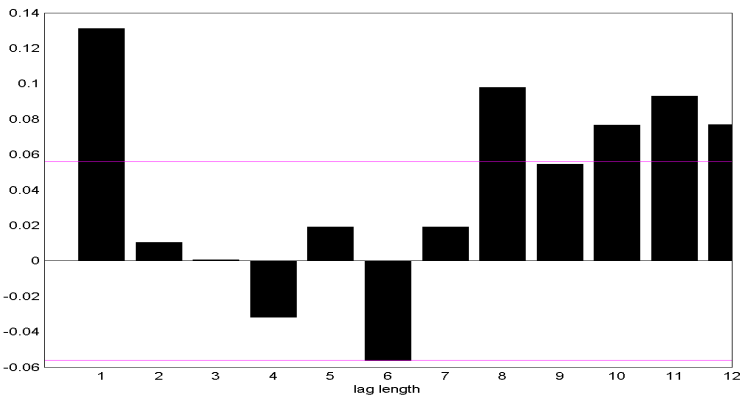

(f) gold

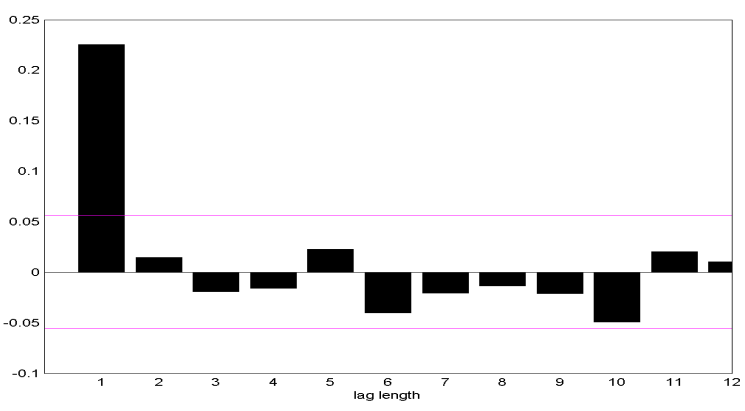

(h) platinum 
Figure 2: Common factors - model: 2 common +3 individual

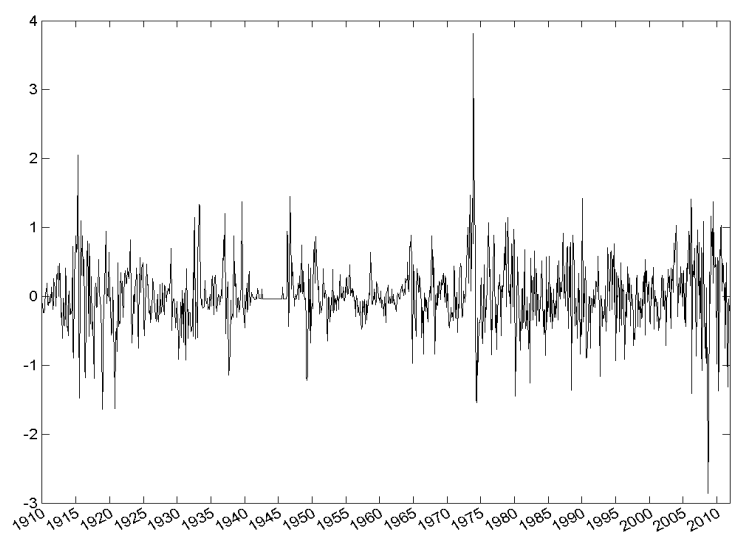

(a) Common factor 1: non-ferrous metals

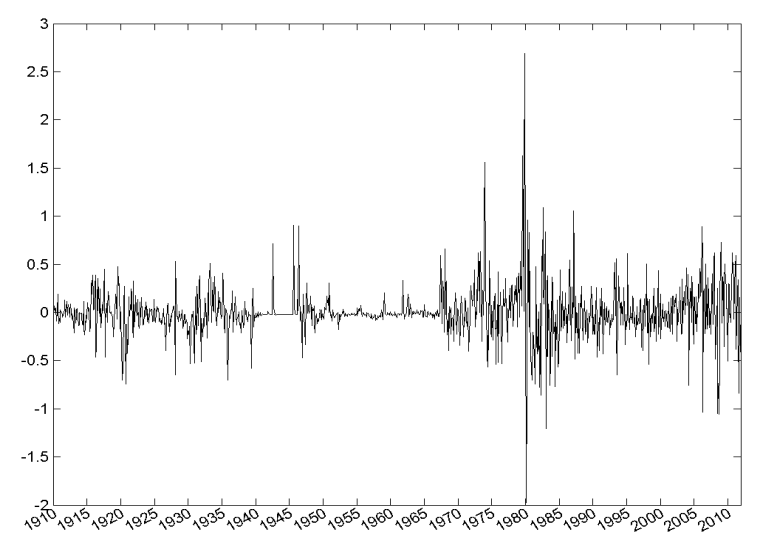

(c) Common factor 2: precious metals

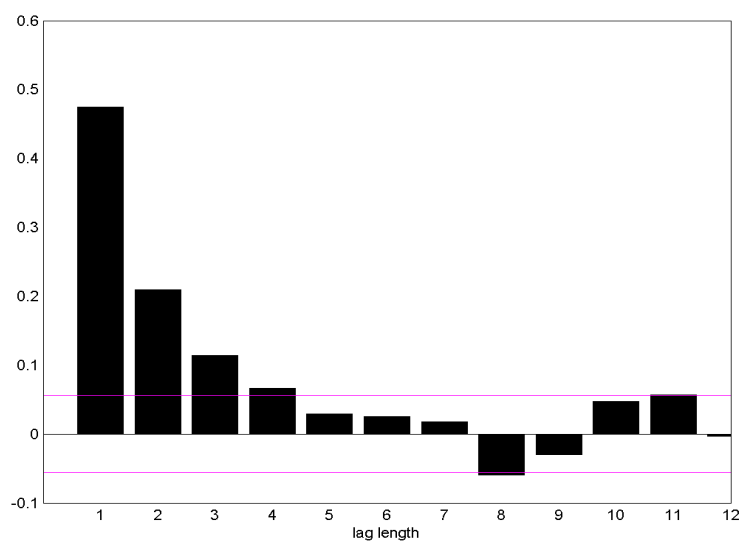

(b) ACF: common factor 1

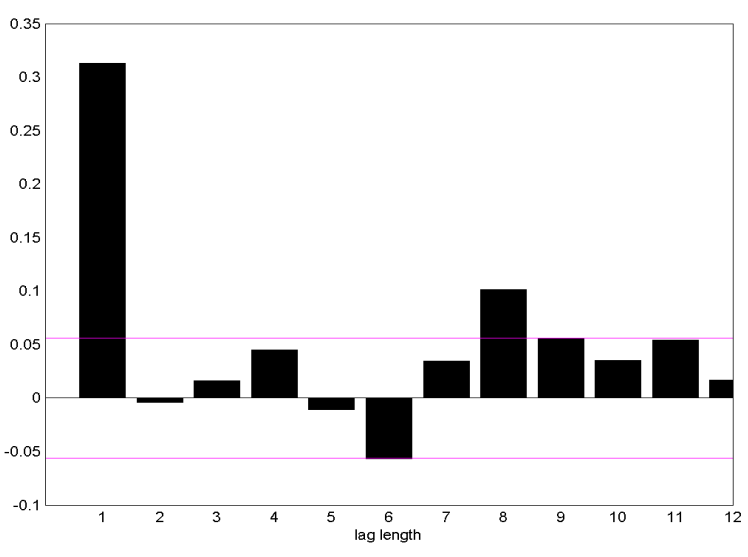

(d) ACF: common factor 2 


\section{A Appendix}

Table A: Data sources and data description

\begin{tabular}{|c|c|c|}
\hline series & information & sources \\
\hline $\operatorname{tin}$ & $\begin{array}{l}\text { 1910-1971: New York, straits tin; 1972-1978: London } \\
\text { Metal Exchange, standard tin; 1979-2011: London } \\
\text { Metal Exchange, min } 99.85 \%\end{array}$ & $\begin{array}{l}\text { 1910-1971: American Metal Market, 1972-1978: } \\
\text { Qiang (1998), Qiang and Weber (1995), 1979-2011: } \\
\text { Federal Institute for Geosciences and Natural } \\
\text { Resources }\end{array}$ \\
\hline zinc & $\begin{array}{l}\text { 1910-1930: East St. Louis, prime western zinc; } \\
\text { 1931-1970: East St. Louis, common metallic zinc; } \\
\text { 1971-1978: London Metal Exchange, common } \\
\text { metallic zinc; 1979-2011: London Metal Exchange, } \\
\text { special high grade, min } 99.95 \%\end{array}$ & $\begin{array}{l}\text { 1910-1930: American Metal Market, 1931-1978: U.S. } \\
\text { Geological Survey, 1979-2011: Federal Institute for } \\
\text { Geosciences and Natural Resources }\end{array}$ \\
\hline lead & $\begin{array}{l}\text { 1910-1929: New York, pig lead; 1930-1960: New } \\
\text { York; 1961-2011: London Metal Exchange, min } 99.97 \\
\%\end{array}$ & $\begin{array}{l}\text { 1910-1929: American Metal Market, 1930-1960: U.S. } \\
\text { Geological Survey, 1961-2011: Federal Institute for } \\
\text { Geosciences and Natural Resources }\end{array}$ \\
\hline copper & $\begin{array}{l}\text { 1910-1927: New York, casting copper; 1928-1959: } \\
\text { United States, electrolytic copper; 1960-2011: } \\
\text { London Metal Exchange, grade A }\end{array}$ & $\begin{array}{l}\text { 1910-1927: American Metal Market, 1928-1959: U.S. } \\
\text { Geological Survey, 1960-2011: Federal Institute for } \\
\text { Geosciences and Natural Resources }\end{array}$ \\
\hline aluminum & $\begin{array}{l}\text { 1910-1959: New York, no. } 1 \text { virgin, min 98-99 \%; } \\
\text { 1960-1968: London Metal Exchange, high grade, min } \\
\text { 99.7 \%; 1969: unalloyed ingot; 1970-2011: London } \\
\text { Metal Exchange, high grade, min } 99.7 \%\end{array}$ & $\begin{array}{l}\text { 1910-1978: American Metal Market, 1960-1968: } \\
\text { Federal Institute for Geosciences and Natural } \\
\text { Resources, 1969: Engineering and Mining Journal, } \\
\text { 1970-2011: Federal Institute for Geosciences and } \\
\text { Natural Resources }\end{array}$ \\
\hline gold & $\begin{array}{l}\text { 1910-1931: London; 1932-1937: London; 1938-1949: } \\
\text { prices fixed; 1950-1969: London; 1970-1978: US } \\
\text { monthly selling prices; 1979-2011: London, } 99.9 \%\end{array}$ & $\begin{array}{l}\text { 1910-1931: Warren et al. (1932), 1932-1937: } \\
\text { American Metal Market, 1950-1969: Deutsche } \\
\text { Bundesbank, 1970-1978: U.S. Geological Survey, } \\
\text { 1979-2011: Federal Institute for Geosciences and } \\
\text { Natural Resources }\end{array}$ \\
\hline silver & $\begin{array}{l}\text { 1910-1978: New York, London; 1979-2011: London, } \\
99.5 \%\end{array}$ & $\begin{array}{l}\text { 1910-1978: American Metal Market, 1979-2011: } \\
\text { Federal Institute for Geosciences and Natural } \\
\text { Resources }\end{array}$ \\
\hline platinum & 1910-1978: New York; 1979-2011: London, $99.95 \%$ & $\begin{array}{l}\text { 1910-1978: American Metal Market, 1979-2011: } \\
\text { Federal Institute for Geosciences and Natural } \\
\text { Resources }\end{array}$ \\
\hline industrial production & $2007=100$, total, United States (U.S.) & $\begin{array}{l}\text { 1910-1919: Miron and Romer (1990), 1920-2011: } \\
\text { Federal Reserve }\end{array}$ \\
\hline crude oil price & WTI, global spot, close, USD (average of daily prices) & Macrobond (code: wocaes0076) \\
\hline S\&P 500 index & $\begin{array}{l}\text { index, USD, Price return, End of Period, United } \\
\text { States }\end{array}$ & Standard \& Poor's \\
\hline consumer price index & all items, total, United States, 1982-1984=100 & U.S. Bureau of Labor Statistics \\
\hline real interest rate & $\begin{array}{l}\text { 1910-1967: index of yields of high grade corporate } \\
\text { and municipal bonds; 1968-2011: government } \\
\text { benchmark, } 10 \text { year, yield, average of period }\end{array}$ & $\begin{array}{l}\text { 1910-1967: NBER Macrohistory Database; } \\
\text { 1968-2011: Macrobond (code: us10ygov_ma) }\end{array}$ \\
\hline
\end{tabular}


HWWI Research Papers

since 2014

155 What are metal prices like? Co-movement, price cycles and long-run trends Anja Rossen, November 2014

154 A Spatial Computable General Equilibrium Model for the Analysis of Regional Climate Change Impacts and Adaptation Policies

Malte Jahn, August 2014

153 The Role of a Changing Market - Environment for Credit Default Swap Pricing Julian Sebastian Leppin, Stefan Reitz, August 2014

152 Tax sovereignty and feasibility of international regulations for tobacco tax policies

Michael Bräuninger, July 2014

151 Entwicklung und Determinanten des Siedlungsabfallaufkommens in Deutschland Jan-Ove Erichsen, Friso Schlitte, Sven Schulze, Juni 2014

150 Changing patterns of electricity use in European manufacturing: a decomposition analysis Lars Wenzel, André Wolf, June 2014

149 Who is overeducated and why? Probit and dynamic mixed multinomial logit analyses of vertical mismatch in East and West Germany Christina Boll, Julian Sebastian Leppin, Klaus Schömann, May 2014

148 Welfare implications of power rationing: an application to Germany Lars Wenzel, André Wolf, February 2014

147 Overeducation among graduates: An overlooked facet of the gender pay gap? Evidence from East and West Germany

Christina Boll, Julian Sebastian Leppin, January 2014 
The Hamburg Institute of International Economics (HWWI) is an economic think tank. The HWWI is a non-profit research organisation (gemeinnützige $\mathrm{GmbH}$ ), privately funded, independent and committed to the principles of a Social Market Economy. Through our research work, we assume responsibility for and contribute to a free, progressive and open society.

Value-free science, open-ended research and methodological pluralism characterise our work. By doing so, we commit ourselves to rules on Safeguarding Good Scientific Practice.

The HWWI operates in the following research areas, acting in a scientific and consultancy capacity:

- Economic Trends and Global Markets,

- Regional Economics and Urban Development,

- Sectoral Change: Maritime Industries and Aerospace,

- Institutions and Institutional Change,

- Energy and Raw Material Markets,

- Environment and Climate,

- Demography, Migration and Integration,

- Labour Economics, Economics of Education, Family Economics,

- Health and Sports Economics,

- Family Owned Business, and

- $\quad$ Real Estate and Asset Markets. 
Hamburg Institute of International Economics (HWWI)

Heimhuder Str. 71 | 20148 Hamburg | Germany

Phone: +49 (0)40 340576 - 0 | Fax: +49 (0)40 340576 - 776

info@hwwi.org | www.hwwi.org 